\title{
Communication of nursing students in listening to patients in a psychiatric hospital
}

\author{
A comunicação do estudante de enfermagem na escuta de pacientes em hospital psiquiátrico \\ Comunicación del estudiante de enfermería en la escucha de pacientes en hospital psiquiátrico
}

Albert Lengruber de Azevedo ${ }^{1}$ Sílvia Teresa Carvalho de Araújo $^{1}$ João Mário Pessoa Júnior ${ }^{1}$ Jaqueline da Silva ${ }^{1}$ Bruna Tavares Uchoa dos Santos ${ }^{1}$ Soraia do Socorro Furtado Bastos ${ }^{1}$

1. Federal University of Rio de Janeiro. Rio de Janeiro, RJ, Brazil.
Corresponding Author:

Albert Lengruber de Azevedo.

E-mail: albertenfermagem@yahoo.com.br

Submitted on $11 / 15 / 2016$.

Accepted on 02/03/2017.

DOI: 10.1590/2177-9465-EAN-2016-0325

\section{Abstract}

Qualitative exploratory and descriptive study with the aim of analyzing the communication of nursing students in the listening to patients in mental suffering admitted in a psychiatric hospital. The study was carried out from April to May 2013, with 23 nursing students regularly enrolled in a public higher education institution in the Southeast of Brazil. The data were collected based on artistic production and interviews, analyzed and categorized according to their thematic content. Proxemic nonverbal communication was unanimously indicated by the students based on personal-body position of face, neck, and, shoulders adopted in the listening to patients in mental suffering. The conscious use of proxemics favored clinical reasoning, improving interaction and listening in speech and thought disorders. Attentive, effective, and affective listening demands availability, control of fear tension, anxiety, and insecurity.

Keywords: Nursing Education; Communication; Nursing Students; Mental Health; Nursing Care.

\section{Resumo}

Pesquisa qualitativa, exploratória e descritiva, com o objetivo de analisar a comunicação do estudante de enfermagem na escuta de pacientes em sofrimento psíquico internados em um hospital psiquiátrico. Foi realizada entre abril e maio de 2013 , com 23 estudantes de enfermagem regularmente matriculados em instituição pública de Ensino Superior da Região Sudeste do Brasil. Os dados foram coletados a partir de produção artística e entrevista, e analisados e categorizados segundo conteúdo temático. A comunicação não verbal proxêmica foi unanimemente apontada pelos estudantes a partir da posição pessoal-corporal do rosto, pescoço e ombros, adotada na escuta dos pacientes em sofrimento psíquico. $\mathrm{O}$ uso consciente da proxemia favoreceu o raciocínio clínico, melhorando a interação e a escuta nas desordens da fala e do pensamento. Uma escuta atenta, efetiva e afetiva demanda disponibilidade, controle do medo, da tensão, da ansiedade e da insegurança.

Palavras-chave: Educação em enfermagem; Comunicação; Estudantes de enfermagem; Saúde mental; Cuidados de enfermagem.

\section{Resumen}

Investigación cualitativa, exploratoria y descriptiva, con el objetivo de analizar la comunicación del estudiante de enfermería en la escucha de pacientes con sufrimiento psíquico internados en hospital psiquiátrico. Realizada entre abril y mayo de 2013 , con 23 estudiantes de enfermería con matrícula regular en institución pública de Enseñanza Superior de la región Sudeste de Brasil. Datos recolectados a partir de producción artística y entrevista, y analizados y categorizados por contenido temático. La comunicación no verbal proxémica fue unánimemente señalada por los estudiantes a partir de la posición personal-corporal del rostro, cuello y hombros adoptada en la escucha de pacientes con sufrimiento psíquico. El uso consciente de la proxemia facilitó el razonamiento clínico, mejorando la interacción y la escucha en desórdenes del habla y del pensamiento. Una escucha atenta, efectiva y afectiva demanda disponibilidad, control del temor, la tensión, la ansiedad y la inseguridad.

Palabras clave: Educación en enfermería; Comunicación; Estudiantes de enfermaría; Salud mental; Atención de enfermaría. 


\section{INTRODUCTION}

In the nursing education process, communication in the listening to patients in mental suffering constitutes an important reflection for healthcare education. ${ }^{1-3}$ This tool is appointed as an essential competence for this future professional, considering person, family, and collectivity in the complexity that involves the care process and its foundation.

In the hospital environment, communication is the main responsible for making interpersonal relations clear and highlighting the importance of mutual respect and clinical reasoning, which are processes inherent to decision making that must be based on critical thoughts and phenomena of nursing interest. Evaluation, in this context, assumes a cornerstone position in health care. ${ }^{4}$

Many hospital scenes are still directed to the daily performance of actions, plans, evaluation, and results in health, depriving reflection of privilege in the listening to patients, which corresponds to the awakening of consciousness on their own attitudes; caution, necessary to strengthen communication; and worldviews and outlines that retrace the whole professional education process. . $^{5,6}$

Proxemics is the communication defined as the social meaning of space and interactive field, which determines, through distances and proximities among people, how interpersonal relationships occur. The intimate distance is maintained in approximately $45 \mathrm{~cm}$; personal from $45 \mathrm{~cm}$ to $1 \mathrm{~m} 20 \mathrm{~cm}$; social from $1 \mathrm{~m} 20 \mathrm{~cm}$ to $3 \mathrm{~m} 60 \mathrm{~cm}$; and public from $3 \mathrm{~m} 60 \mathrm{~cm}$ until limits of visibility or hearing. ${ }^{7}$

In nursing education, listening is presented as a valuable resource to obtain, achieve, and learn emotional, cognitive, behavioral, and therapeutic communication skills, when providing students with tools, without limiting their performance to only one direction, that is, to processes of capture, interpretation of information, and undertaking of care practices that demand impartiality and neutrality. ${ }^{1-3}$ The sociopetal axis is defined in this context as the dimension that analyzes the angle of the shoulders in relation to another person, that is, that checks the position of interlocutors (face to face, with their backs to each other, or in any other angulation). The sociofugal axis, in turn, implies the reverse: in discouragement of interaction. ${ }^{7}$

Listening does not only happen through the ears, but with the whole soul, glances, hands, body gestures, clothing, movement of lips, and heart, accepting others with empathy and respect. ${ }^{3}$ Students must be aware of this resource, because as they are given tools to achieve their know-how, the decoding of verbal and non-verbal aspects, recognition of facial position and body posture, interest and attentive look to manifestations of others, and search for information inherent to the affective and emotional field, desires, expectations, tensions, anguishes, and fears of everyone are favored by clinical reasoning and creative sense. .,8,9 $^{3}$

Considering this context, the following guiding question was outlined for the present study: How does communication of nursing students occur in the listening to patients in mental suffering admitted in a psychiatric hospital? The aim of the present study was to analyze the communication of nursing students in the listening to patients in mental suffering admitted in a psychiatric hospital.

\section{METHOD}

A qualitative exploratory and descriptive study was carried out based on artistic production and semi-structured interviews regarding the communication in the listening to patients in mental suffering admitted in a psychiatric hospital, which occurred in two meetings. The first meeting occurred prior to the beginning of practical activities in mental health and the second, at the end of the term, from April to May 2013, respectively.

Twenty-three nursing students from a public higher education institution located in the city of Rio de Janeiro in the Southeast of Brazil participated in the study. The inclusion criteria were being 18 years or older; being regularly enrolled in the seventh term of the undergraduate course in nursing; and having concluded $70 \%$ of the theoretical-practical contents of the course. The exclusion criteria were being present in only one of the proposed meetings and having previous experience in the care of patients in mental suffering.

The setting for data collection was a classroom. Access to students occurred after contact of the main researcher with the professors responsible for the teaching of theoreticalpractical content in the mental health discipline. Therefore, the two meetings were held based on the discipline's schedule of activities, both tied to a breakfast called "affective breakfast" and a relaxation technique to the sound of instrumental and ambient music, whose purpose was to bring the researcher closer to the group.

The first meeting had an average duration of 40 minutes and included the presentation of the general aspects of the study, reading of the informed consent form, signature of the participants, and individual distribution of an A4 sheet for a free drawing, showing the communication adopted in the listening to patients in mental suffering, with a space for writing a word or phrase summarizing what was drawn. In the enunciation phase, all students shared their ideas in the making of the drawing, promoting a collective discussion that enabled the clarification of doubts, presentation of stories, and personal accounts.

After the first meeting, transcriptions, thorough reading, exhaustive rereading of the recorded interviews, and triangulation together with words or phrases written in the drawings were carried out in the reclusion's phase.

Before the second meeting, another printed instrument was also individually distributed, made up of a question on the communication adopted in the listening to patients in mental suffering. After the instructions, a minimum period of 10 minutes was set for its completion.

The reading and rereading of the material produced in the two meetings were carried out, as well as the regrouping of the drawings according to criteria of similarities and differences in contents and their ideas. After this stage, thematic content analysis was carried out. ${ }^{10}$ The thematic category identified 
was about the influence of proxemic verbal and nonverbal communication in listening.

In accordance with the ethical precepts for human research, the study was approved by a research ethics committee under protocol no. 260.221/13. In the presentation of extracts of the statements in the results, the anonymity of the participants was ensured, and their names were substituted for the letter $\mathrm{E}$, followed by the order of categorization of the research data: 1 , 2,3 , up to 23 .

\section{RESULTS}

Most of the participants were women, and a total of 19 were single students aged from 20 to 24 years old.

A main thematic unit was established based on the analysis and interpretation of the findings, called "Communication of nursing students in the listening to patients in mental suffering" and its respective definitions, namely: "Listening as a means for understanding the meanings of verbal communication", "Listening as a communication channel", "Listening as an act of being available", "Listening as proxemics", "Listening beyond listening to words", "Listening as observation of actions and behaviors", "Listening as an attitude of solidarity", and "Listening as support".

Chart 1 presents the main thematic category and its respective units of definition, in addition to the main extracts of the statements that characterize each of them.

The students identified listening as an opportunity to understand the meanings of verbal communication, in addition to being a communication channel between students-patients in mental suffering. The act of being available to listen to patients was shared as an opportunity to learning, since knowing to listen demanded sensitivity, impartiality, neutrality, giving, and respect, just like it was shared.

Proxemics, the position adopted in the interaction among people, was highlighted as a communication form that helps in listening. When sharing that listening went beyond listening to words, the students considered that they had to be often available to listen to patients in mental suffering. Although listening is a possibility in different hospital environments, the students emphasized that in order to make it effective, solidarity, attitudes to help, understanding, availability, and support are required.

\section{DISCUSSION}

There was a prevalence of young single women in the present study. The reduced number of participants considered the total of students enrolled in the undergraduate course in nursing, which was positive to its development, and worked as a guide to the learning and acquisition of skills essential for professional education, such as listening, clinical reasoning, effective and affective communication, and interpersonal relationship. ${ }^{4,11}$

In this experience, the establishment of a dialogic space with nursing students for sharing the drawings favored interpersonal relationship. This practice highlighted the need for purifying senses that live and take longer in time, in care, and in communication among people. Widely accepted in nursing, this teaching strategy is part of the fundamental basis of the nursing education process. ${ }^{3,12}$

For students, when engaging in a dialogue with patients, it is important to be open, without dubious expressions, face to face, establishing a satisfactory communication. Only in this way can a simple and effective mechanism be developed, enabling to listen based on an appropriate language and to value nonverbal communication to provide comfort, encouragement, and trust to patients.

Relying on therapeutic techniques of communication includes knowing how to listen; using silence therapeutically; being interested in what is said; and accepting it. All these stages must happen naturally, with a posture as relaxed as possible, relaxed body, uncrossed arms and legs, and horizontal vision to favor visual contact and empathy. ${ }^{4}$

If the patient is silent, excluded, and crestfallen, students should not adopt an invasive behavior. ${ }^{3}$ The sociofugal axis is then imposed by the distance maintained intentionally, which is a result prioritized by the interaction in public zones. ${ }^{7,13}$

Personal space and territoriality are two important concepts exposed by proxemics. The first refers to a kind of invisible bubble, in which proximity may or may not be tolerated and is modified according to the type of personal relationship; and the second is the changeable area that individuals demand as theirs, with the purpose of providing safety and maintaining autonomy, privacy, and personal identity. ${ }^{8}$

The participants also shared that communication is essential for care, and is especially based on the understanding of meanings. They consider the creation of a therapeutic space as a need for making the listening to patients in mental suffering affective and effective. This space must favor, in addition to the undertaking of nursing techniques, mutual respect, empathy, and authenticity of relationships. ${ }^{1}$

In the healthcare area, listening can be described as the act of giving appropriate attention to the person who is speaking, or even mean an action that helps in the early evaluation of what is said, not said, or interdicted by people. ${ }^{4,14}$ In nursing, listening may translate an attitude or demand to the acquisition of therapeutic communication skills. To make it effective in nursing education, before any academic obligation, it is important to consolidate the environment and make it positive for care. ${ }^{4}$ This is possible through the conscious use of empathy, friendliness, kindness, mutual respect, and good communication.

When made aware of listening and having a third listener as eventual help, students considered that their ability to understand theory and practice improved significantly, since they were able to learn how to work on the self with regard to what they establish as their reality. ${ }^{15}$ Listening does not start with interpreting, but with suspending all judgment, trying to understand by empathy, senses and meanings that exist in care practice or situation. ${ }^{6}$

The teaching of communication with valorization of the approach to proxemics was able to produce reactions and changes in nursing students, through the positive feedback in 
Chart 1. Main thematic categories and their respective units of definition.

\begin{tabular}{|c|c|}
\hline \multicolumn{2}{|c|}{ Communication of nursing students in the listening to patients in mental suffering } \\
\hline $\begin{array}{l}\text { Listening as a means for understanding the } \\
\text { meanings of verbal communication }\end{array}$ & $\begin{array}{l}\text { I drew two people. (...) in the case of listening! Not only with nurses, but } \\
\text { also with professionals. (E.14) }\end{array}$ \\
\hline Listening as a communication channel & $\begin{array}{l}\text { I think that through listening, patients will tell you everything they are } \\
\text { feeling. Sometimes a moan of pain, a smile, any sound (...) anything they } \\
\text { reproduce to you, everything will have a meaning. (E.11) } \\
\text { When you are listening to what they are saying, you are giving attention. } \\
\text { (...) sometimes you end up intervening, saying something that makes } \\
\text { sense, (...) you are only looking at them, but you are there. That is why it is } \\
\text { good to know how to listen. (E.13) }\end{array}$ \\
\hline Listening as an act of being available & $\begin{array}{l}\text { When you are listening to what they are saying, you are giving attention. } \\
\text { (...) sometimes you end up intervening, saying something that makes } \\
\text { sense, (...) you are only looking at them, but you are there. That is why it is } \\
\text { good to know how to listen. (E.13) }\end{array}$ \\
\hline Listening as proxemics & $\begin{array}{l}\text { My intention was to try to listen to patients. Anguishes (...) worries, to } \\
\text { be able to see what you can do for them. Because it is very easy to leave } \\
\text { patients there, silent, excluded, crestfallen. Now, it is completely different } \\
\text { if you go there to talk to them, check what is happening, and see what is } \\
\text { going on in their minds. (E.17) }\end{array}$ \\
\hline Listening beyond listening to words & $\begin{array}{l}\text { The difficulty they present. (...) Looking at them, we can see it very clearly. } \\
\text { (E.11) } \\
\text { When I look at patients, I feel them fragile, very fragile indeed. (E.13) }\end{array}$ \\
\hline $\begin{array}{l}\text { Listening as observation of actions and } \\
\text { behaviors }\end{array}$ & $\begin{array}{l}\text { Through listening, you can sense the structure of the thought, through } \\
\text { language. I have even tried echolalia, perseverance, among other things } \\
\text { that can be denied by vision. (...) I thought about the issue of the order of } \\
\text { thought. (E.10) }\end{array}$ \\
\hline Listening as an attitude of solidarity & $\begin{array}{l}\text { When communication is effective, meaning when family is present, } \\
\text { when they talk about things that are happening outside, (...) about their } \\
\text { anguishes, the patients' condition always improved. (E.10) } \\
\text { Active listening and watchful eye are the best tools to provide special care. } \\
\text { It is wonderful! It makes care more effective! (...) moreover, I drew an ear } \\
\text { here to show that we must listen to patients, to show the importance of } \\
\text { listening to patients. (E.15) }\end{array}$ \\
\hline Listening as support & $\begin{array}{l}\text { Listening is one of the main things, even if it is delirium, hallucination. } \\
\text { Because by listening, you can take measures, no matter how tired you are, } \\
\text { after an exhaustive shift, listening would be the key (E.14) (...) Listening is } \\
\text { something that we learn during the course, but sometimes it seems to be } \\
\text { forgotten, especially with psychiatric patients. (E.14) }\end{array}$ \\
\hline
\end{tabular}

the way of seeing, feeling, and listening to people. The dialogic space built in this experience helped in the translation of ways through which the participants placed and moved themselves in relation to others, and how they managed the space for listening. ${ }^{1,2}$ In synthesis, proxemic communication was presented as a facilitating tool in the teaching-learning process, for the opportunity of interaction with people. However, it is important to know how to explore it, not only through verbal language, but also based on the environment-person relationship, in which people influence environment and vice versa. ${ }^{13}$
The difficulty in listening to other people is in the fact that everybody carries their own suppositions in form of values, beliefs, meanings, reasons, purposes, and objectives. ${ }^{16}$ When listening is sensitive, they accept to be surprised by the unknown, since this action, which is more than an art, tries to circumscribe an universe and propose reference models until proved otherwise. ${ }^{17}$ If human care is the main role of nursing, its complexity must be emphasized, with a focus on the understanding and respect through attentive and sensitive listening. ${ }^{16}$ 
To awake this knowledge on the students, it was necessary to encourage them to listen to others and make them aware of a care practice that demands, in addition to knowledge on psychic structure, languages, behaviors and sequencing of thoughts, a greater awareness on who the person is, ${ }^{1}$ placing them as the main focus in mental healthcare. ${ }^{3}$

Listening, depending on the situation, may be a way to expand a starting point. ${ }^{16}$ Listening without interferences, agreeing or disagreeing with what is said, may be understood as an attitude of respect for others. Agreeing may not necessarily mean to be at the mercy of what others are saying, in the same way that disagreeing does not imply defending one's own opinions. ${ }^{16}$ Therefore, promoting learning in an active way is important, awakening critical thought in students, and leading them to the development and acquisition of skills based on acting, listening, and feeling. ${ }^{12,18}$

In the evaluation of patients in mental suffering, undergraduate students recognized that echolalia (an immediate or late repetition of words, phrases, and sounds heard and expressed in a decontextualized way) and perseveration (a persistent repetition of ideas on a certain fact, opinion, and inability to modify them) are communication elements indicative of changes in behavior that can be denied by vision and possible recognition through clinical reasoning. ${ }^{17}$

The drawing experience enabled the development of skills essential for decision making of nursing students and favored the recognition of barriers that intervene in the listening to patients in mental suffering, strengths and weaknesses of a therapeutic relationship, and indicative of attention to the interaction among nursing staff, patients, and health institutions. ${ }^{2,3,15}$

In the present study, the proxemic communication unanimously stood out among those adopted by nursing students to listen, as it values the personal-body position, face, neck, and shoulders, maintained in the interaction and care directed to patients with mental disorders. ${ }^{19}$

It is recognized that part of the communication adopted in listening, in addition to helping the development of positive relationships, involved the recognition of proxemic nonverbal aspects. Each body move or position has different functions: adaptive, expressive, and defensive, some conscious or not; and when they are known, there is an option to assume the daily challenge of consciously undertaking them in favor of interaction. ${ }^{8}$

\section{CONCLUSION}

In this experience, which marked the teaching-learning process in the mental healthcare area, proxemic nonverbal communication was unanimously mentioned by nursing students, because of the valorization of the personal-body position maintained, face, neck, and shoulders during the listening to patients in mental suffering.

Clinical reasoning was presented as an important competence in listening, which, when helping students, favored the recognition of speech and thought disorders, improving interaction and listening. To make this listening attentive, effective, and affective, availability and control of fear, tension, insecurity, movements of proximity and distancing, and position adopted to listen are required.

The opening of a space for establishing proxemic communication in nursing education is recommended, with a focus on strategies and skills inherent to listening by future professionals in several care environments.

\section{REFERENCES}

1. McKenna L, Brown T, Boyle M, Williams B, Palermo C, Molloy E. Listening and communication styles in nursing students. J Nurs Educ Pract [Internet]. 2014; [cited 2017 Jan 16]; 4(11):50-8. Available from: http://www.sciedu.ca/journal/index.php/jnep/article/view/4741/3266

2. Pazargadi M, Fereidooni Moghadam M, Fallahi Khoshknab M, Alijan Renani H, Molazem Z. The Therapeutic Relationship in the Shadow: Nurses' Experiences of Barriers to the Nurse-Patient Relationship in the Psychiatric Ward. Issues Ment Health Nurs [Internet]. $2015 \mathrm{Jul}$ [cited 2017 Jan 6]; 36(7):551-7. Available from: http://www.tandfonline.com/ doi/abs/10.3109/01612840.2015.1014585?journalCode=imhn20

3. Azevedo AL, Araújo STC, Vidal VLL. How nursing students perceive communication with patients in mental health. Acta Paul Enferm [Internet] 2015 [cited 2017 Jan 16]; 28(2):125-31. Available from: http://www. scielo.br/scielo.php?pid=S0103-21002015000200125\&script=sci arttext\&tlng=en http://dx.doi.org/10.1590/1982-0194201500022

4. Mathevula FR, Khoza LB. Nurse educators and student nurse neophytes perceptions of good interaction in the classroom setting. Health SA Gesondheid [Internet]. 2013; [cited 2017 Jan 16]; 18(1):[ aprox. 9 telas] Available from: http://www.hsag.co.za/index.php/HSAG/article/view/669 doi: 10.4102/hsag.v18i1.669

5. Paes MR, Maftum MA. Communication between nursing team and patients with mental disorder in an emergency service. Ciênc Cuid Saúde [Internet]. 2013 Jan/Mar; [cited 2017 Jan 16]; 12(1):5561. Available from: http://www.periodicos.uem.br/ojs/index.php/ CiencCuidSaude/article/view/15830/pdf_1 http://dx.doi.org/10.4025/ cienccuidsaude.v12i1.15830

6. Jorge MS, Pinto DM, Quinderé PD, Pinto AG, Sousa FS, Cavalcante CM. Promotion of Mental Health - Technologies for Care: emotional involvement, reception, co-responsibility and autonomy. Ciênc Saúde Coletiva [Internet]. 2011 [cited 2017 Jan 16]; 16(7):3051-60. Available from: http://www.scielo.br/scielo.php?script=sci_arttext\& pid=S1413-81232011000800005 http://dx.doi.org/10.1590/S141381232011000800005

7. Hall ET. A Dimensão oculta. São Paulo: Martins Fontes; 2005.

8. Prochet TC, Silva MJP. Proxêmica e cinésica como recursos comunicacionais entre o profissional de saúde e o idoso hospitalizado. Rev Enferm UERJ [Internet]. 2012 Jul/Set [cited 2017 Jan 16]; 20(3):349-54. Available form: http://www.e-publicacoes.uerj.br/index. php/enfermagemuerj/article/view/2337

9. Wyder M, Bland R, Blythe A, Matarasso B, Crompton D. Therapeutic relationships and involuntary treatment orders: Service users' interactions with health-care professionals on the ward. Int J Ment Health Nurs [Internet]. 2015 Apr [cited 2017 Jan 16]; 24(2):181-9. Available from: http://onlinelibrary.wiley.com/doi/10.1111/inm.12121/abstract;js essionid=E994B6DAAD03E294F1880621D1771FF7.f01t01? userlsA uthenticated=false \&deniedAccessCustomisedMessage $=$

10. Bardin L. Análise de conteúdo. Lisboa: Edições 70; 2011. 279p.

11. Farrelly S, Lester H, Rose D, Birchwood M, Marshall M, Waheed W, et al. Improving Therapeutic Relationships - Joint Crisis Planning for Individuals With Psychotic Disorders. Qual Health Res [Internet]. 2015 Dec [cited 2016 Jan 16]; 25(12):1637-47. Available from: http://journals. sagepub.com/doi/abs/10.1177/1049732314566320?url_ver=Z39.882003\&rfr_id=ori:rid:crossref.org\&rfr_dat=cr_pub\%3dpubmed doi $10.1177 / 1049732314566320$ 
12. Zamanzadeh V, Valizadeh L, Azimzadeh R, Aminaie N, Yousefzadeh D. First and Fourth-Year Student's Perceptions about Importance of Nursing Care Behaviors: Socialization toward Caring. J Caring Sci [Internet]. 2014 Jun 1 [cited 2017 Jan 16]; 3(2):93-101. Available from: https://www.ncbi.nlm.nih.gov/pmc/articles/PMC4134170/doi:10.5681/ jcs.2014.010.

13. Terra AC, Vaghetti HH. Proxemics Communication in Nursing work: an integrative literature review. Cienc Enferm [Internet]. 2014; [cited 2017 Jan 18]; 20(1):23-34. Available from: http://www.scielo.cl/scielo. php?script=sci_arttext\&pid=S0717-95532014000100003 http://dx.doi. org/10.4067/S0717-95532014000100003

14. Bax AMC, Araujo STC. No verbal expression from the patient in care: perception of the nurse in cardio intensive care unit. Esc Anna Nery [Internet]. 2012 Out/Dez; [cited 2017 Jan 16]; 16(4):728-33. Available from: http://www.scielo.br/scielo.php?script=sci_arttext\& pid=S1414-81452012000400012 http://dx.doi.org/10.1590/S141481452012000400012

15. Menezes SSC, Correa CG, Gengo e Silva RC, Cruz DAML. Clinical reasoning in undergraduate nursing education: a scoping review. Rev Esc Enferm USP [Internet]. 2015; [cited 2017 Jan 16]; 49(6):10329. Available from: http://www.scielo.br/pdf/reeusp/v49n6/00806234-reeusp-49-06-1037.pdf http://dx.doi.org/10.1590/S0080623420150000600021
16. Camillo SO, Nóbrega MPSS, Theo NC. Nursing undergraduate students' view on listening to patients during care delivery. Rev Esc Enferm USP [Internet]. 2010 [cited 2017 Jan 16]; 44(1):99106. Available from: http://www.scielo.br/scielo.php?pid=S008062342010000100014\&script=sci_arttext\&tlng=en http://dx.doi. org/10.1590/S0080-62342010000100014

17. Franzoi MAH, Santos JLG, Backes VMS, Ramos FRS. Musical intervention as a nursing care strategy for children with autism spectrum disorder at a psychosocial care center. Texto Contexto Enferm [Internet] 2016 [cited 2017 Jan 16]; 25(1):e1020015. Available from: http://www. scielo.br/scielo.php?pid=S0104-07072016000100701\&script=sci arttext\&tIng=en http://dx.doi.org/10.1590/0104-070720160001020015

18. Souza DN, Souza FN. Nursing Teaching Strategies by Encouraging Students' Questioning, Argumentation and Explanation. Rev Esc Enferm USP [Internet]. 2014 [cited 2017 Jan 16]; 48(Sp2):155-63. Available from: http://www.scielo.br/scielo.php?script=sci_arttext\&p $\mathrm{id}=\mathrm{S} 0080-62342014000800155 \mathrm{http}: / / \mathrm{dx}$. doi.org/10.1590/S0080623420140000800023

19. Carvalho EC, Cruz DALM, Herdman TH. Contribuição das linguagens padronizadas para a produção do conhecimento, raciocínio clínico e prática clínica da Enfermagem. Rev Bras Enferm [Internet]. 2013 [cited 2017 Jan 16]; 66(Spe):134-41. Available from: http://www.scielo.br/ scielo.php?script=sci_arttext\&pid=S0034-71672013000700017 http:// dx.doi.org/10.1590/S0034-71672013000700017 